\title{
FORMULASI MOCAF, TEPUNG UBI JALAR UNGU DAN JELAI TERHADAP SIFAT SENSORIS, ANTIOKSIDAN, NILAI GIZI, PROFIL FTIR DAN INDEKS GLIKEMIK BERAS ANALOG
}

\section{THE FORMULATION OF MOCAF, SWEET PURPLE POTATO AND BARLEY FLOUR ON SENSORY PROPERTIES, ANTIOXIDANT, NUTRITIONAL VALUE, FTIR PROFILE, AND GLYCEMIC INDEX OF RICE ANALOGUE}

\author{
Bernatal Saragih, Hairun Nisyawati, Betrik Sitohang, Catherine Novita Sari \\ Sigalingging dan Marwati \\ Jurusan Teknologi Hasil Pertanian, Fakultas Pertanian, Universitas Mulawarman \\ Jl. Pasir Balengkong Kampus Gunung Kelua Samarinda \\ Email : saragih_bernatal@yahoo.com
}

Diterima : 19-9-20

Direvisi : 7-12-20

Disetujui : 16-12-20

\begin{abstract}
ABSTRAK
Diversifikasi pangan sangat penting dilakukan untuk perbaikan ketahanan pangan dan gizi, salah satu pendekatan dapat dilakukan dengan pembuatan beras analog dari berbagai tepung-tepungan yang berasal dari bahan baku non beras. Penelitian bertujuan untuk mengetahui pengaruh formulasi mocaf, tepung ubi jalar ungu dan tepung jelai terhadap uji sensoris, antioksidan, nilai gizi, Profil FTIR dan indeks glikemik beras analog. Metode penelitian dengan tahapan proses pembuatan tepung, pencampuran, pembuatan adonan, steaming dan pencetakan. Hasil penelitian menunjukkan beras analog yang diformulasi dari mocaf, tepung ubi jalar ungu dan tepung jelai secara organoleptik dapat diterima. Aktivitas antioksidan ( $\mathrm{IC}_{50}$ ) beras analog berkisar antara $115,33 \pm 1,1$ sampai $242,8 \pm 0,31 \mu \mathrm{g} / \mathrm{ml}$. Nilai gizi beras analog dari perlakuan terpilih $50 \mathrm{~g}$ tepung ubi jalar ungu, $40 \mathrm{~g}$ dan tepung jelai $10 \mathrm{~g}$, memiliki kadar air 5,71\%, kadar abu 0,73\%, kadar lemak 3,94\%, kadar protein 2,29\%, kadar karbohidrat $87,26 \%$ dan total energi 393,69 kkal. Hasil anlisis FTIR menunjukkan bahwa ikatan kimia yang ditemukan pada beras analog $\mathrm{C}-\mathrm{H}, \mathrm{O}-\mathrm{H}, \mathrm{C}=\mathrm{C}$ dan $\mathrm{NO}_{2}$. Indeks glikemik beras analog sebesar 33,15 (rendah) dan muatan glikemik sebesar 28,92 (kategori tinggi).
\end{abstract}

Kata kunci: antioksidan, beras analog, FTIR, indeks glikemik, nilai gizi

\begin{abstract}
Food diversification is very important as an effort to improve food security and nutrition example of diversification is the manufacture of analog rice from various starches derived from non-rice raw materials. The aim of this study was to determine the effect of the formulation of mocaf, purple sweet potato flour and barley flour on sensory tests, antioxidants, nutritional value, FTIR profile and glycemic index of analog rice. The research method consisted of the stages of the process of making flour, mixing, making dough, steaming and forming. The results showed that the analog rice formulated from mocaf, purple sweet potato flour and barley flour was organoleptically acceptable. The antioxidant activity (IC $\left.C_{50}\right)$ of analog rice ranged from $115.33 \pm 1.1$ to $242.8 \pm 0.31 \mu \mathrm{g} / \mathrm{ml}$. The nutritional value of analog rice from the selected treatment of mocaf $50 \mathrm{~g}$ purple sweet potato flour $40 \mathrm{~g}$ and $10 \mathrm{~g}$ barley flour, had a moisture content of $5.71 \%, 0.73 \%$ ash, 3.94\% fat, 2.29\% protein, 87 carbohydrates, $26 \%$ and energy $393.69 \mathrm{kcal}$. FTIR analysis results showed that the chemical bonds found in analog rice were $\mathrm{C}-\mathrm{H}, \mathrm{O}-\mathrm{H}, \mathrm{C}=\mathrm{C}$ and $\mathrm{NO}_{2}$. The glycemic index of analog rice was 33.15 (low) and the glycemic load was 28.92 (high category).
\end{abstract}

Key words: antioxidants, analog rice, FTIR, glycemic index, nutritional value 


\section{PENDAHULUAN}

onsumsi beras penduduk Indonesia masih tinggi yaitu $113,4 \mathrm{~kg} / \mathrm{kapita} / \mathrm{tah} u n$ pada tahun 2017, tahun 2018 menurun menjadi 111, $58 \mathrm{~kg} / \mathrm{kapita} / \mathrm{tahun}$ dan pada tahun 2019 menurun menjadi 94,9 kg/kapita/tahun (BKP, 2020). Beras merupakan salah satu sumber karbohidrat dan sumber pangan utama di Indonesia. Sumber energi untuk aktivitas sehari-hari masyarakat Indonesia $50 \%$ berasal dari jenis serealia, terutama beras, sehingga ketergantungan masyarakat terhadap beras sangat tinggi (Saragih, et al., 2019).

Pemerintah terus berupaya dalam meningkatkan konsumsi pangan lokal dengan program diversifikasi untuk menurunkan konsumsi beras. Program diversifikasi pangan non beras yang dipilih Kalimantan Timur dan Utara adalah singkong dengan semboyan "kenyang tidak selalu dengan makan nasi" (BKP, 2020). Salah satu alternatif peningkatan konsumsi pangan lokal dengan diversifikasi dalam produk beras analog juga menjadi pilihan dengan berbahan pangan lokal. Beras analog yang dibuat dengan bahan dasar mocaf (modified cassava flour), ubi jalar ungu dan jelai. Beras analog merupakan tiruan dari beras yang terbuat dari bahan-bahan seperti umbi-umbian dan serealia yang bentuk mirip seperti beras (Samad, 2003). Beras analog dapat dirancang sehingga memiliki kandungan gizi hampir sama bahkan melebihi beras padi, dan juga dapat memiliki sifat fungsional sesuai dengan bahan baku yang digunakan (Noviasari et al, 2013).

Mocaf adalah tepung dari ubi kayu atau singkong yang dibuat dengan menggunakan prinsip modifikasi sel ubi kayu secara fermentasi (Subagio, 2006). Tepung mocaf dijadikan sebagai bahan baku pembuatan beras analog karena tepung mocaf memiliki kandungan kalori dan karbohidrat cukup tinggi yaitu sekitar $>80 \%$ dari bobot kering (Hutami et al., 2014). Warna tepung mocaf lebih putih dibandingkan tepung singkong dikarenakan terjadi kehilangan komponen pembentuk warna saat proses fermentasi (Subagio et al.,2008).

Ubi jalar ungu (Ipomoea batatas L.poir) dapat berfungsi sebagai pengganti beras karena merupakan sumber karbohidrat (Handawi, 2010). Kandungan karbohidrat ubi jalar ungu yang tinggi dijadikan sebagai sumber kalori. Selain itu kandungan ubi jalar ungu termasuk ke dalam golongan low glycemic index yaitu merupakan jenis karbohidrat yang apabila dikonsumsi tidak akan meningkatkan kadar gula darah dalam tubuh secara drastis (Ginting et al., 2011).

Jelai (Coix lachryma-jobi L) dapat dimanfaatkan sebagai pangan fungsional (Zhu, 2017; Saragih, 2018), jelai mengandung komposisi gizi yang baik dalam setiap $100 \mathrm{~g}$, dengan kandungan protein 15,4 g, Karbohidrat 65,3 g, Ca 25 mg, p 435 mg, Fe 5 mg, B1 0,28 mg, B2 0,19 mg, dan Niacin 4,3 mg (Tajalifar, 2018; ). Hasil analisis Jelai PJ SR diperoleh indeks glikemiknya 54,69 (kategori rendah), hasil ini menunjukkan bahwa jelai sangat penting untuk makanan bagi pasien diabetes (Saragih et al., 2018). Hasil studi Saragih, et al., (2019), menunjukkan bahwa beras analog dengan bahan dasar mocaf diperoleh lama steaming terbaik adalah 10 menit dengan kadar air 5,04\%, kadar abu $1,49 \%$, protein $22,54 \%$, lemak 4,67\%, karbohidrat 65,45\%, energi $394,04 \mathrm{kkal}$, serta index glikemik 61(sedang) dan muatan glikemik 40. Berdasarkan permasalahan diatas maka dilakukan penelitian yang bertujuan untuk mengetahui pengaruh formulasi mocaf, tepung ubi jalar ungu dan tepung jelai terhadap sifat sensoris, antioksidan, nilai gizi, profil FTIR, serta indeks dan muatan glikemik beras analog yang dihasilkan.

\section{METODELOGI PENELITIAN}

\section{Bahan dan Alat}

Bahan yang dipakai adalah ubi jalar ungu yang diperoleh dari pasar dayak di Samarinda, jelai diperoleh dari Loa Kulu Kutai Kartanegara dan tepung mocaf diperoleh dari BPTP Samarinda, Gliseril Monostearat (GMS) (Merck), air, garam, DPPH (1,1 diphenyl-2- 
Dicrylhidrazyl)Sigma Chemical Co, St. Lois, MO), etanol 95\%, $\mathrm{NaOH}\left(\right.$ Merck), $\mathrm{H}_{2} \mathrm{SO}_{4}$ (Merck), $\mathrm{H}_{3} \mathrm{BO}_{3}$ (Merck), $\mathrm{HCl}$ (Merck), boiling chips. Alat yang digunakan dalam penelitian ini, baskom, talenan, pisau, saringan, oven (Memmert UN 110), accu chek active blood lancet, strip analisis glukosa, FTIR (Thermo Nicolet IS 10).

\section{Metode}

Rancangan percobaan yang digunakan pada penelitian ini yaitu Rancangan Acak Lengkap (RAL) dengan 6 taraf (faktor) perlakuan dan 3 kali ulangan masing-masing formulasi tepung mocaf dengan tepung ubi jalar ungu dan tepung jelai. Perlakuan yang dikerjakan dalam penelitian ini adalah sebagai berikut $\mathrm{p} 0=50 \mathrm{~g}$ mocaf $: 0 \mathrm{~g}$ tepung ubi jalar ungu:50 g tepung jelai, $\mathrm{p} 1=50 \mathrm{~g}$ mocaf, $10 \mathrm{~g}$ tepung ubi jalar ungu : $40 \mathrm{~g}$ tepung jelai, p2 $=50 \mathrm{~g}$ mocaf, $20 \mathrm{~g}$ tepung ubi jalar ungu :30 g tepung jelai, p3=50 g mocaf, $30 \mathrm{~g}$ tepung ubi jalar ungu :20 g tepung jelai, p4=50 g mocaf: $40 \mathrm{~g}$ tepung ubi jalar ungu : $10 \mathrm{~g}$ tepung jelai, $\mathrm{p} 5=50 \mathrm{~g}$ mocaf: $50 \mathrm{~g}$ tepung ubi jalar ungu :0 $\mathrm{g}$ tepung jelai. Penelitian ini terdiri dari tiga tahap kegiatan, yaitu: pertama pembutan tepung ubi jalar ungu, jelai, kemudian pengolahan beras analog berbahan dasar tepung mocaf, tepung ubi jalar ungu dan tepung jelai dengan perlakuan lama steaming 10 menit, ketiga analisa parameter.

\section{Pembuatan Tepung Ubi Jalar Ungu dan Jelai}

Proses pembuatan tepung ubi jalar ungu dimulai dengan mengupas kulit hingga merata, kemudian daging ubi jalar ungu direndam dalam air selama 2 jam, karena mengandung getah yang banyak dan dicuci menggunakan air bersih dan ditiriskan, serta dipotong setebal $2 \mathrm{~mm}$. Selanjutnya, daging ubi jalar ungu direndam dengan $1 \mathrm{ppm}$ natrium bisulfit selama 15 menit, perendaman ini dilakukan untuk mencegah pencoklatan pada daging ubi jalar ungu. Langkah berikutnya, ubi jalar ungu dikeringkan dengan oven pada suhu $60^{\circ} \mathrm{C}$ selama 16 jam dan dihaluskan dengan menggunakan blender agar diperoleh butiran tepung kasar, kemudian hasilnya akan diayak dengan ayakan 80 Mesh agar diperoleh butiran halus tepung ubi jalar ungu (Saragih, 2013). Proses pembuatan tepung jelai diawali dengan pengayakan jelai untuk menghilangkan kotoran dari jelai. Setelah itu, jelai dikeringkan dalam oven selama 2 jam dengan suhu $60^{\circ} \mathrm{C}$ agar kadar air dalam jelai berkurang. Kemudian, jelai dihaluskan dan diayak menggunakan ayakan 80 Mesh.

\section{Pengolahan Beras Analog}

Pengolahan beras analog dimulai terlebih dahulu dengan menyiapkan bahan baku seperti tepung mocaf, tepung ubi jalar ungu dan tepung jelai sesuai dengan perlakuan masing-masing. Kemudian, dimasukkan ke dalam wadah dan ditambahkan air sebanyak $100 \mathrm{~mL}$ serta minyak sawit $20 \mathrm{~mL}$ dan GMS sebanyak $5 \mathrm{~g}$. Adonan diaduk hingga menjadi kalis selama \pm 5 menit. Setelah itu, adonan mengalami tahap pra-gelatinisasi yaitu tahapan dimana adonan di steaming atau dikukus pada suhu $85^{\circ} \mathrm{C}$ dengan lama steaming yaitu 10 menit (Saragih, et al., 2019).

Adapun tujuan dari proses steaming ini untuk menyeragamkan kadar air dalam bahan dan membuat bahan bersifat lebih higroskopis sehingga membuat tahap ekstrusi lebih cepat. Setelah itu, adonan dicetak menggunakan alat penggiling daging yang pelatnya telah dimodifikasi berbentuk bulatan yang lebih kecil dari pelat penggiling daging pada umumnya, lalu dipotong dengan ukuran menyerupai beras atau dengan panjang $\pm 1 \mathrm{~cm}$. Butiran beras kemudian dikeringkan dalam oven pengering $70^{\circ} \mathrm{C}$ selama 3 jam lalu akan diperoleh beras analog. Beras analog kemudian dilakukan uji sensoris, antioksidan sesuai perlakuan serta nilai gizi dan uji FTIR pada formulasi terpilih. 
Pada uji organoleptik, dilakukan proses pemasakan beras yaitu dengan cara dikukus. Panci kukus yang berisi air dipanaskan terlebih dahulu kemudian dimasukkan beras analog $150 \mathrm{~g}$ kedalam panci kukus. Beras analog diletakkan merata dan dipercik dengan air hingga terlihat basah. hal ini dilakukan agar tekstur nasi tidak lembek. Setelah itu, panci ditutup dan dikukus selama 20-25 menit. Nasi analog yang telah matang diangkat dan dilakukan uji organoleptik, dan perlakuan terpilih dilakukan uji indeks glikemik dan muatan glikemik.

\section{Analisis Parameter}

Uji Organoleptik yaitu uji kesukaan hedonik dan mutu hedonik dengan menggunakan 7 skala terhadap 25 orang panelis agak terlatih. Skor yang diberikan untuk atribut warna, aroma, tekstur, rasa dan keseluruhan adalah $1=$ sangat tidak suka, 2= tidak suka, 3= agak tidak suka, $4=$ biasa saja, $5=$ agak suka, $6=$ suka, $7=$ sangat suka. Untuk mutu hedonik warna beras analog $1=$ Putih, $2=$ Agak putih, $3=$ Agak ungu, 4=Ungu kemerahan, $5=$ Ungu, $6=$ Ungu kecoklatan, 7=Coklat,. Aroma yaitu 1=Amat sangat beraroma jelai, $2=$ Sangat beraroma jelai, $3=$ Beraroma jelai, $4=$ Agak beraroma ubi jalar ungu, $5=$ Beraroma ubi jalar ungu, 6=Sangat beraroma ubi jalar ungu, 7=Amat sangat beraroma ubi jalar ungu. Tekstur yaitu 1=Amat sangat rapuh, 2=Sangat rapuh, 3=Rapuh, 4=Agak keras, $5=$ Keras, $6=$ Sangat keras, $7=$ Amat sangat keras. Uji mutu hedonik setelah dimasak (nasi analog) untuk warna, dan aroma sama skala mutunya, sedangkan untuk tekstur yaitu $1=$ Amat sangat tidak pulen, 2=Sangat tidak pulen, 3=Tidak pulen, 4=Agak pulen, 5=Pulen, $6=$ Sangat pulen, $7=$ Amat sangat pulen dan rasa yaitu $1=$ Amat sangat berasa jelai, $2=$ Sangat berasa jelai, $3=$ =Berasa jelai, $4=$ Agak berasa ubi jalar ungu, $5=$ =Berasa ubi jalar ungu, $6=$ Sangat berasa ubi jalar ungu, $7=$ Amat sangat berasa ubi jalar ungu.

\section{Aktivitas Antioksidan}

Uji aktivitas antioksidan dilakukan dengan metode spektrofotometri dengan DPPH (2,2-diphenyl-I-picryhydrazyl). Sebanyak $5 \mathrm{~mL}$ ekstrak yang telah diencerkan dalam etanol $5 \mathrm{~mL}$, kemudian tambahkan $2 \mathrm{~mL}$ bahan dan $2 \mathrm{~mL}$ DPPH $(0,15 \mathrm{mM}$ dalam etanol) pada saat yang sama dalam tabung reaksi, kontrol yang terdiri atas DPPH $2 \mathrm{~mL}$ dengan $2 \mathrm{~mL}$ etanol disiapkan. Campuran reaksi dicampur dengan baik lalu diinkubasi dalam keadaan gelap pada suhu ruang selama 24 jam kemudian disaring. Absorbansi diukur pada $575 \mathrm{~nm}$. Aquades digunakan sebagai kontrol positif dan etanol digunakan sebagai blanko. Kemampuan DPPH ekstrak dihitung dengan menggunakan persamaan berikut:

$$
\text { aktivitas antioksidan }=\frac{\text { (absorbansi kontrol-absorbansi sampel) }}{\text { absorbansi kontrol }} \times 100 \%
$$

Absorbansi kontrol adalah absorbansi DPPH + etanol

Absorbansi sampel adalah absorbansi DPPH radikal + sampel (Shekar, et al., 2014)

\section{Analisa kimia dan Gizi}

Analisa kadar air, analisa kadar abu, analisa kadar lemak (metode soxhlet) dan analisa kadar protein (metode Kjeldahl) (Sudarmadji et al., 2010). Analisa kadar karbohidrat dengan metode by difference (Winarno, 2008) dan analisa total energi (AOAC, 2005).

\section{Analisa Profil Kimia dengan FTIR}

Uji FTIR Thermo Nicolet IS 10 (Detector Type : Deuterated TriGlycine Sulfate [DTGS]), Accessories : Smart ATR Diamond. Spektrum FTIR direkam pada spektrometer Nicolet iS10 FT-IR yang dilengkapi dengan berlian sel kristal untuk operasi refleksi total 
yang dilemahkan (ATR). Spektrum diperoleh (32 scan per filesampel atau latar belakang) dalam kisaran 4000-600 $\mathrm{cm}^{-1}$ dengan resolusi nominal $4 \mathrm{~cm}^{-1}$ (Durazzo, et al., 2018a).

\section{Uji Indeks Glikemik dan Muatan Glikemik}

Uji Indeks Glikemik (IG) (Miller et al., 1996; Saragih, 2013), Responden puasa dari jam 8 malam sampai jam 8 pagi, kemudian pada jam 8 pagi diberikan pangan sampel. Pengambilan darah dilakukan dalam interval waktu 30 menit sebanyak 5 kali (menit ke 0 , 30, 60, 90, dan 120) sejumlah $50 \mu \mathrm{L}$ (finger-prick capillary blood samples method). Analisis glukosa menggunakan alat Accu Chek Active. Darah akan diambil melalui pembuluh darah kapiler pada jari responden. Untuk menentukan IG adar glukosa darah akan diplot (setiap waktu sampling) pada dua sumbu, yaitu sumbu waktu (X) dan sumbu glukosa ( $Y$ ). IG ditentukan dengan membandingkan luas daerah dibawah kurva antara pangan yang diukur IG-nya dengan pangan acuan dikalikan 100. Perhitungan Muatan Glikemik (Passos, et al., 2014; Passos, et al., 2015).

\section{Analisis Data}

Hasil data uji organoleptik yang diperoleh diolah dengan sidik ragam dan dianalisis menggunakan uji Krukal-Wallis (non-parametrik), Antioksidan dengan Anova dan jika terdapat perbedaan yang nyata pada taraf a $5 \%$, dilanjutkan dengan uji beda nyata jujur (BNJ) (Steel and Torrie, 1995).

\section{HASIL DAN PEMBAHASAN}

Hedonik Beras dan Nasi Analog

Hasil penilaian organoleptik terhadap hedonik warna, aroma, tekstur, rasa beras dan nasi analog disajikan pada Tabel 1.

Tabel 1. Organoleptik beras dan nasi analog

\begin{tabular}{|c|c|c|c|c|c|c|c|}
\hline \multirow{2}{*}{$\begin{array}{l}\text { Karakteristik } \\
\text { Organoleptik }\end{array}$} & \multirow{2}{*}{ Parameter } & \multicolumn{6}{|c|}{ Perlakuan } \\
\hline & & PO & P1 & P2 & P3 & P4 & P5 \\
\hline \multirow{4}{*}{$\begin{array}{l}\text { Hedonik } \\
\text { Beras }\end{array}$} & Warna & $4,89 a$ & 4,69ab & $5,3 a$ & $5,2 a$ & $4,72 a$ & $4,97 a$ \\
\hline & Aroma & 4,77 & 4,92 & 4,94 & 4,85 & 4,94 & 4,88 \\
\hline & Tekstur & 5,10 & 5,14 & 5,05 & 5,01 & 4,97 & 5,17 \\
\hline & Warne & $4,22 \mathrm{~cd}$ & $4,04 d$ & $5,1 a$ & $\begin{array}{l}5,04 a \\
3,73 a\end{array}$ & $4,85 a b c$ & $5,06 a$ \\
\hline \multirow[t]{3}{*}{ Hedonik Nasi } & Aroma & $4,33 b$ & 4,57ab & $4,92 a b$ & b & $4,97 a b$ & $5,04 a$ \\
\hline & Tekstur & 4,29 & 4,57 & 4,73 & 4,3 & 4,68 & 4,61 \\
\hline & Rasa & $4,45 b$ & $4,53 b$ & $4,69 a b$ & $5,08 a$ & $4,84 a$ & $5,18 a$ \\
\hline
\end{tabular}

Keterangan: 1 = sangat tidak suka, $2=$ tidak suka, $3=$ agak tidak suka, $4=$ biasa saja, $5=$ agak suka, $6=$ suka, $7=$ sangat suka. Data rata-rata diperoleh dari 6 perlakuan dan 3 ulangan. Data pada kolom yang sama dengan diikuti huruf yang sama menunjukkan berbeda tidak nyata pada Uji BNJ taraf a $5 \%$.

\section{Hedonik Warna beras dan nasi analog}

Warna beras dan nasi analog yang dihasilkan memiliki nilai hedonik warna diatas 4 (biasa saja) sampai 5 (agak suka) (Tabel 1). Nasi analog yang dihasilkan pada penelitian ini berwarna ungu kecokelatan. Hal ini dipengaruhi oleh warna tepung ubi jalar ungu.Semakin tinggi penambahan tepung ubi jalar ungu pada beras analog, maka semakin tinggi pula penilaian panelis terhadap warna beras dan nasi analog. Semakin tinggi konsentrasi ubi jalar ungu yang diberikan maka warna ungu yang ada pada nasi analog semakin cerah karena kandungan antosianin dari ubi jalar ungu (Qi, et al., 2015). Antosianin dapat mempengaruhi warna dan berubah selama proses pemasakan atau penggunaan panas (Sui, et al., 2016). Berdasarkan hasil sidik ragam diketahui bahwa formulasi mocaf, tepung 
ubi jalar ungu dan tepung jelai berpengaruh nyata terhadap hedonik warna beras dan nasi analog yang dihasilkan. Hasil uji BNJ menunjukkan bawah warna beras analog semua perlakuan berbeda tidak nyata.

\section{Hedonik Aroma beras dan nasi analog}

Nilai hedonik aroma pada beras analog yang dihasilkan biasa saja (skor 4). Semakin tinggi penambahan tepung ubi jalar ungu, maka semakin terasa aroma khas dari beras analog yang dihasilkan, hal ini dikarenakan aroma jelai kurang mendominasi aroma beras analog karena proporsi tepung ubi jalar ungu merupakan yang paling banyak dibanding tepung yang lain. Sementara tepung mocaf cenderung tidak memiliki aroma yang tajam, namun setelah melalui proses pencampuran dan pemasakan dapat terjadi interaksi bahan yang menimbulkan aroma yang khas. Tepung ubi jalar ungu memberikan kontribusi dominan terhadap aroma nasi analog. Berdasarkan hasil sidik ragam menunjukkan bahwa formulasi mocaf, tepung ubi jalar ungu dan tepung jelai berpengaruh tidak nyata terhadap hedonik aroma dari beras analog, sedangkan pada hedonik aroma dari nasi analog analog berpengaruh nyata (Tabel 1). Aroma beras analog berdasarkan uji BNJ semua perlakuan berbeda tidak nyata.

\section{Hedonik Tekstur Beras dan Nasi Analog}

Rata rata hasil uji hedonik tekstur nasi yang didapatkan berkisar antara 4,29 (biasa saja) hingga 5,17 (agak suka). Berdasarkan hasil sidik ragam diketahui bahwa formulasi mocaf, tepung ubi jalar ungu dan tepung jelai berpengaruh tidak nyata terhadap hedonik tekstur beras dan nasi analog yang dihasilkan (Tabel 1). Tekstur beras analog berdasarkan uji BNJ semua perlakuan berbeda tidak nyata.

\section{Mutu Hedonik Beras dan Nasi analog}

Hasil penilaian organoleptik terhadap mutu hedonik warna, aroma, tekstur, rasa beras dan nasi analog ditunjukkan pada Tabel 2.

Tabel 2. Mutu hedonik beras dan nasi analog

\begin{tabular}{llcccccc}
\hline \multirow{2}{*}{$\begin{array}{l}\text { Karakteristik } \\
\text { Organoleptik }\end{array}$} & Parameter & \multicolumn{7}{c}{ Perlakuan } \\
\cline { 3 - 7 } & & P0 & P1 & P2 & P3 & P4 & P5 \\
\hline Mutu & Warna & $1,9 \mathrm{~d}$ & $3,61 \mathrm{c}$ & $5,52 \mathrm{~b}$ & $5,32 \mathrm{~b}$ & $5,82 \mathrm{ab}$ & $6,36 \mathrm{a}$ \\
Hedonik & Aroma & $3,10 \mathrm{c}$ & $3,66 \mathrm{c}$ & $3,84 \mathrm{cb}$ & $3,86 \mathrm{cb}$ & $4,21 \mathrm{ab}$ & $4,65 \mathrm{a}$ \\
Beras & Tekstur & $4,48 \mathrm{ab}$ & $4,61 \mathrm{ab}$ & $5,01 \mathrm{a}$ & $4,61 \mathrm{ab}$ & $4,73 \mathrm{ab}$ & $4,49 \mathrm{a}$ \\
\hline \multirow{2}{*}{ Mutu } & Warna & $2,45 \mathrm{c}$ & $4,37 \mathrm{~b}$ & $5,42 \mathrm{a}$ & $5,80 \mathrm{a}$ & $5,73 \mathrm{a}$ & $5,66 \mathrm{a}$ \\
Hedonik Nasi & Aroma & $3,25 \mathrm{dc}$ & $3,78 \mathrm{c}$ & $4,69 \mathrm{~b}$ & $4,82 \mathrm{ab}$ & $5,10 \mathrm{a}$ & $5,18 \mathrm{a}$ \\
& Tekstur & 4,16 & 4,25 & 4,39 & 4,31 & 4,56 & 4,60 \\
& Rasa & $3,12 \mathrm{c}$ & $3,80 \mathrm{~b}$ & $4,29 \mathrm{a}$ & $4,30 \mathrm{a}$ & $4,50 \mathrm{a}$ & $4,66 \mathrm{a}$ \\
\hline
\end{tabular}

Keterangan :Untuk mutu hedonik warna beras 1=Putih, 2=Agak putih, 3=Agak ungu, 4=Ungu kemerahan, $5=$ Ungu, $6=$ Ungu kecoklatan, $7=$ Coklat,. Aroma yaitu $1=$ Amat sangat beraroma jelai, $2=$ Sangat beraroma jelai, $3=$ Beraroma jelai, $4=$ Agak beraroma ubi jalar ungu, $5=$ Beraroma ubi jalar ungu, $6=$ Sangat beraroma ubi jalar ungu, $7=$ Amat sangat beraroma ubi jalar ungu. Tekstur yaitu $1=$ Amat sangat rapuh, 2=Sangat rapuh, 3=Rapuh, 4=Agak keras,5=Keras, 6=Sangat keras, $7=$ Amat sangat keras. Uji mutu hedonik setelah dimasak (nasi analog) untuk warna, dan aroma sama skala mutunya, sedankan untuk tekstur yaitu $1=$ Amat sangat tidak pulen, $2=$ Sangat tidak pulen, $3=$ Tidak pulen, $4=$ Agak pulen, $5=$ Pulen, $6=$ Sangat pulen, $7=$ Amat sangat pulen dan rasa yaitu 1=Amat sangat berasa jelai, 2=Sangat berasa jelai, 3=Berasa jelai, 4=Agak berasa ubi jalar ungu, 5=Berasa ubi jalar ungu, 6=Sangat berasa ubi jalar ungu, 7=Amat sangat berasa ubi jalar ungu. Data rata-rata diperoleh dari 6 perlakuan dan 3 ulangan. Data pada kolom yang sama dengan diikuti huruf yang sama menunjukkan berbeda tidak nyata pada Uji BNJ taraf a $5 \%$. 


\section{Mutu Hedonik Warna Beras dan Nasi Analog}

Mutu hedonik warna beras dan nasi analog sesuai perlakuan dari agak putih sampai ungu kecoklatan (Tabel 2). Warna ungu pada beras analog ubi jalar ungu disebabkan oleh kandungan antosianin. Menurut Leighton et al. (2010) kandungan antosianin pada ubi jalar juga berpotensi sebagai bahan pewarna alami untuk makanan ataupun minuman. Berdasarkan hasil sidik ragam diketahui bahwa formulasi mocaf, tepung ubi jalar ungu dan tepung jelai berpengaruh nyata terhadap mutu hedonik warna beras dan nasi analog yang dihasilkan. Hasil uji BNJ menunjukkan perlakuan P4 dan P5 perlakuan terbaik pada mutu hedonik warna beras analog.

\section{Mutu Hedonik Aroma Beras dan Nasi Analog}

Beras analog dengan formulasi mocaf $50 \mathrm{~g}$, tepung ubi jalar ungu $50 \mathrm{~g}$ dan tepung jelai $0 \mathrm{~g}$ (P5) memiliki daya terima paling baik oleh panelis (Tabel 2). Tepung ubi jalar ungu memberikan kontribusi terhadap aroma beras dan nasi analog. Hasil ini sama dengan hasil penelitian dari Suwikatmono, et al. (2013) perbedaan ubi jalar terhadap bihun berpengaruh terhadap aroma yang dihasilkan. Pada umumnya, masyarakat menyukai nasi yang memiliki aroma wangi. Beras yang mengandung amilosa sedang mempunyai nilai aroma nasi yang lebih tinggi dari pada beras yang beramilosa tinggi (Saragih, et al., 2013). Berdasarkan hasil sidik ragam, diketahui bahwa formulasi mocaf, tepung ubi jalar ungu dan tepung jelai berpengaruh nyata terhadap mutu hedonik aroma beras dan nasi analog yang dihasilkan. Hasil uji BNJ menunjukkan perlakuan P4 dan P5 merupakan perlakuan terbaik (nilai tertinggi) mutu hedonik aroma beras analog.

\section{Mutu Hedonik Tekstur Beras dan Nasi Analog}

Hasil penelitian menunjukkan bahwa mutu hedonik tekstur nasi analog yang dihasilkan dengan nilai tertinggi yaitu pada perlakuan P5 (mocaf 50: ubi jalar ungu 50:jelai 0) dengan skor 4,60 mendapatkan hasil tekstur yang pulen dari panelis dan Perlakuan dengan nilai terendah yaitu pada perlakuan P0 (mocaf 50: ubi jalar ungu 0: jelai 50 ) dengan skor 4,16 dan mendapatkan hasil agak pulen (Tabel 2). Namun demikian kebiasaan masyarakat tentu akan menentukan juga karena ada maysarakat suka nasi pulen adan juga yang kurang pulen atau pera. Semakin lama proses pengukusan, maka tekstur beras yang dihasilkan semakin terbentuk atau pulen. Fungsi pengukusan ini yaitu sebagai proses gelatinisasi awal agar pada saat dimasak beras tidak pecah atau menjadi bubur. Suhu gelatinisasi merupakan suhu ketika mulai terdeteksi terjadinya peningkatan viskositas yang disebabkan oleh pengembangan granula pati. Berdasarkan hasil sidik ragam diketahui bahwa formulasi mocaf, tepung ubi jalar ungu dan tepung jelai berpengaruh nyata terhadap mutu hedonik tekstur beras, akan tetapi tidak pada nasi analog yang dihasilkan. Hasil uji BNJ menunjukkan semua perlakuan berbeda tidak nyata terhadap mutu tekstur beras beras analog.

\section{Mutu Hedonik Rasa Nasi Analog}

Semakin tinggi penambahan tepung ubi jalar ungu, maka semakin manis rasa nasi analog yang dihasilkan (Tabel 2). Rasa manis pada produk pangan diperoleh dari karbohidrat (Saragih, et al., 2019). Rasa dapat dipengaruhi oleh beberapa faktor, yaitu senyawa kimia, suhu, konsentrasi, dan interaksi dengan komponen rasa lain (Winarno, 2008). Berdasarkan hasil sidik ragam diketahui bahwa formulasi mocaf, tepung ubi jalar ungu dan tepung jelai berpengaruh nyata terhadap hedonik dan mutu hedonik rasa nasi analog yang dihasilkan. Hasil uji BNJ menunjukkan perlakuan P2, P3, P4 dan P5 berbeda tidak nyata terhadap rasa nasi analog. 


\section{Aktivitas Antioksidan}

Nilai aktivitas antioksidan dari beras analog dari formulasi mocaf, tepung ubi jalar ungu dan tepung jelai disajikan pada tabel 3.

Tabel 3. Aktivitas antioksidan beras analog

\begin{tabular}{ccc}
\hline Perlakuan & $\mathbf{I C}_{\mathbf{5 0}}(\boldsymbol{\mu g} / \mathbf{m l})$ & Sifat Antioksidan \\
\hline P0 & $242,8 \pm 0,31 \mathrm{e}$ & Lemah \\
P1 & $185,46 \pm 4,84 \mathrm{~d}$ & Lemah \\
P2 & $170,51 \pm 7,44 \mathrm{c}$ & Lemah \\
P3 & $150,63 \pm 8,04 \mathrm{~b}$ & Lemah \\
P4 & $127,07 \pm 3,68 \mathrm{a}$ & Sedang \\
P5 & $115,33 \pm 1,1 \mathrm{a}$ & Sedang \\
\hline
\end{tabular}

Keterangan : Data rata-rata diperoleh dari 6 perlakuan dan 3 ulangan. Data pada kolom yang sama dengan diikuti huruf yang sama menunjukkan berbeda tidak nyata pada Uji BNJ taraf a 5\%.

Berdasarkan hasil sidik ragam menunjukkan bahwa formulasi mocaf, tepung ubi jalar ungu dan tepung jelai berpengaruh nyata terhadap aktivitas antioksidan yaitu nilai IC $_{50}$ beras analog yang dihasilkan. Aktivitas antioksidan beras analog diperoleh nilai $\mathrm{IC}_{50}$ berkisar antara $115,33 \pm 1,1 \mu \mathrm{g} / \mathrm{ml}$ sampai dengan $242,8 \pm 0,31 \mu \mathrm{g} / \mathrm{ml}$. Pada pengujian DPPH diperoleh nilai $\mathrm{IC}_{50}$ tertinggi pada P4 dan P5 dengan nilai aktivitas sedang, sedangkan nilai $\mathrm{IC}_{50}$ terendah dan tergolong lemah terdapat pada sampel beras analog P0 yaitu 242,8 $\mu \mathrm{g} / \mathrm{ml}$. Berdasarkan hasil Uji BNJ (Beda Nyata Jujur) menunjukkan bahwa aktivitas antioksidan beras analog P0 berbeda nyata dengan P1, P1 berbeda nyata dengan P2, P2 berbeda nyata dengan P3 (Tabel 3). Perbedaan aktivitas antioksidan ini disebabkan oleh penambahan tepung ubi jalar ungu. Hal ini dapat terjadi oleh karena adanya reduksi radikal DPPH oleh antioksidan, semakin tinggi konsentrasi tepung ubi jalar ungu maka partikelpartikel senyawa antioksidan yang terkandung akan semakin banyak sehingga semakin besar pula aktivitas antioksidannya dan menyebabkan absorbansi DPPH semakin berkurang (Talapessy et al., 2013). Vitamin C sebagai kontrol positif memiliki nilai IC $_{50}$ yaitu 53,20 ppm yang tergolong kuat. Berdasarkan data yang diperoleh, dapat dilihat bahwa absorbansi DPPH semakin berkurang seiring dengan bertambahnya konsentrasi tepung ubi jalar ungu. Hasil penelitian Marfuatul dan Saragih, (2018) menunjukkan bahwa penambahan tepung daun singkong dapat meningkatkan aktivitas antioksidan beras analog yang dihasilkan. Hasil uji aktivitas antioksidan terbaik adalah pada perlakuan P4 dan P5. Berdasarkan uji organoleptik dan aktivitas antioksidan diperoleh perlakuan terbaik adalah P4 dan P5, kemudian dilanjukan untuk uji nilai gizi.

\section{Nilai Gizi}

Perlakuan terpilih diambil berdasarkan nilai $\mathrm{IC}_{50}$ terbaik yaitu perlakuan P4 dan P5 sama-sama nilai IC $_{50}$ tergolong sedang (Tabel 4). Nilai gizi pada perlakuan terpilih dari beras analog dari formulasi mocaf, tepung ubi jalar ungu dan tepung jelai disajikan pada Tabel 4. Berdasarkan hasil Independent T-test menunjukkan bahwa nilai gizi beras analog hasil formulasi tepung ubi jalar ungu dan tepung jelai P4 (40:10) dengan P5 (50:0) berbeda nyata untuk semua parameter yaitu kadar air, kadar abu, kadar lemak, kadar protein, kadar karbohidrat dan total energi.

Berdasarkan hasil Independent T-test menunjukkan bahwa nilai gizi beras analog hasil formulasi tepung ubi jalar ungu dan tepung jelai P4 (40:10) dengan P5 (50:0) berbeda nyata untuk semua parameter yaitu kadar air, kadar abu, kadar lemak, kadar protein, kadar karbohidrat dan total energi. Kadar air yang tertinggi terdapat pada P5 yaitu sebesar $7,51 \%$. Kadar air beras analog hasil formulasi tepung ubi jalar ungu dan tepung 
jelai ini masih berada di bawah $14 \%$ sehingga masih tergolong jauh di bawah kadar air untuk pertumbuhan kapang.

Table 4. Nilai gizi beras analog

\begin{tabular}{lcc}
\hline \multirow{2}{*}{ Parameter } & \multicolumn{2}{c}{ Nilai Gizi } \\
\cline { 2 - 3 } & P4 & P5 \\
\hline Kadar air (\%) & $5,71 \pm 0,12 \mathrm{a}$ & $7,51 \pm 0,10 \mathrm{~b}$ \\
Kadar abu (\%) & $0,73 \pm 0,12 \mathrm{a}$ & $2,33 \pm 0,12 \mathrm{~b}$ \\
Kadar lemak (\%) & $3,94 \pm 0,04 \mathrm{a}$ & $2,95 \pm 0,02 \mathrm{~b}$ \\
Kadar protein (\%) & $2,29 \pm 0,01 \mathrm{a}$ & $1,95 \pm 0,01 \mathrm{~b}$ \\
Kadar karbohidrat (\%) & $87,26 \pm 0,09 \mathrm{a}$ & $85,20 \pm 0,09 \mathrm{~b}$ \\
Total energi (kkal) & $393,69 \pm 0,68 \mathrm{a}$ & $375,12 \pm 0,52 \mathrm{~b}$ \\
\hline
\end{tabular}

Kadar lemak pada beras analog dipengaruhi oleh formulasi dari tepung jelai yang memiliki kandungan lemak yang cukup tinggi yaitu 7,9\% per $100 \mathrm{~g}$. Kadar lemak pada tepung ubi jalar ungu tergolong sangat rendah (Auoran, et al, 2019). Kadar karbohidrat yang diperoleh sudah cukup tinggi karena adanya kandungan karbohidrat dari tepung mocaf, tepung ubi jalar ungu dan tepung jelai berkisar antara $83-89 \%$ yang merupakan sumber karbohidrat. Energi beras analog berbanding lurus dengan karbohidrat karena semakin tinggi kadar karbohidrat beras analog maka akan semakin tinggi pula kadar energi beras analog (Saragih, et al., 2013). Berdasarkan hasil uji Independent T-test nilai gizi terbaik adalah P4 dibandingkan dengan P5, sehingga P4 dilanjutkan untuk uji FTIR dan indeks glikemik.

\section{Profil FTIR (Fourier Transform Infra Red) Beras Analog}

Hasil analisis profil kimia beras analog dengan p4 (50 g mocaf:40 g tepung ubi jalar ungu :10 g tepung jelai), disajikan pada Gambar 1.

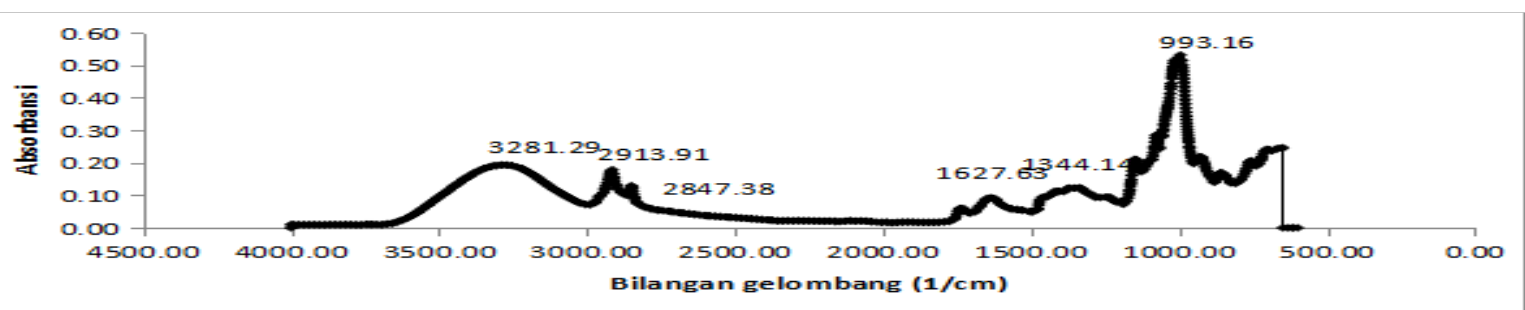

Gambar 1. Profil FTIR beras analog

Berdasarkan spektrum FTIR yang diperoleh bilangan gelombang 3281.29 merupakan representasi serapan ikatan $\mathrm{O}-\mathrm{H}$ tekuk, 2913.91 serapan ikatan $\mathrm{C}-\mathrm{H}$ dan 2847,38 serapan ikatan C-H tekuk. Rentang serapan 2500 sampai 2000 tidak jelas, rentang serapan 2000 sampai 1500 ada serapan ikatan 1627.63 ikatan $\mathrm{C}=\mathrm{C}$ tekuk. Rentang serapan IR 1500 ke 400 ada dua yaitu pada 1344.14 yang merupakan daerah serapan ikatan $\mathrm{NO}_{2}$ dan 993.16 yang merupakan daerah serapan tertinggi ikatan $\mathrm{C}-\mathrm{H}$ tekuk yang merupakan unsur pembentuk senyawa karbohidrat atau gula yang mempengaruhi juga indeks glikemik pangan. Serapan ikatan $\mathrm{O}-\mathrm{H}$ merupakan pembentuk senyawa fenol (flavonoid) yang merupakan antioksidan pangan (Skoog et al., 1998; Hardiana et al., 2012; Durazzo, et al., 2018b; Lucarini ,et al., 2018).

\section{Indeks Glikemik dan Muatan Glikemik}

Respon gula darah masing-masing 10 orang responden yang mengkonsumsi roti tawar, gula (pembanding) dan nasi analog dengan perlakuan p4 (50 g mocaf:40 g tepung ubi jalar ungu :10 g tepung jelai) disajikan dalam bentuk grafik pada Gambar 2 . 


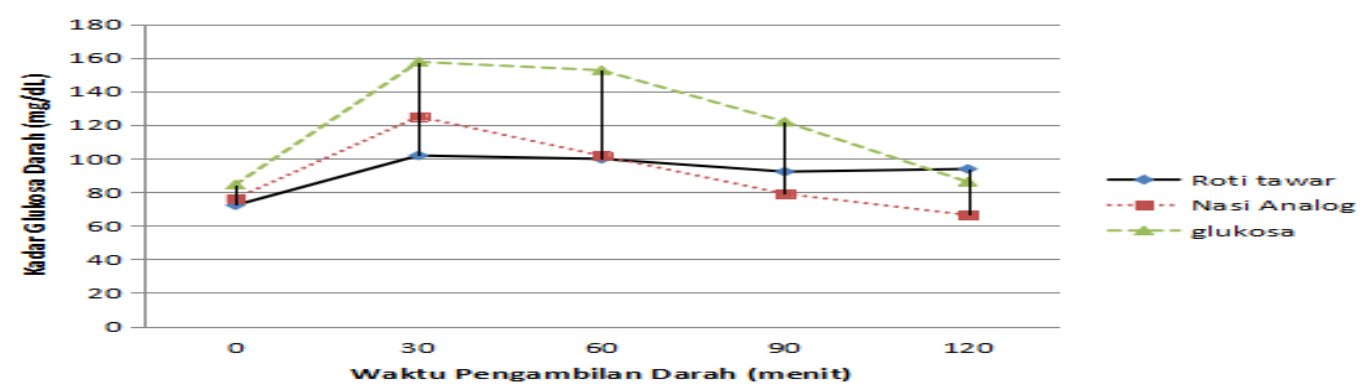

Gambar 2. Respon glukosa darah setelah konsumsi beras analog menggomas

Nilai Indeks Glikemik (IG) nasi analog yang dihasilkan adalah 33,51 (kategori rendah). Nilai indeks glikemik dalam bahan pangan dipengaruhi oleh beberapa faktor diantaranya jenis bahan, cara pengolahan dan komposisi serta sifat biokimiawi pangan. Oleh karena itu, meskipun bahan pangan tersebut sama, apabila diolah dengan cara yang berbeda maka dapat diperoleh indeks glikemik yang berbeda pula (Saragih, 2014; Marfuatul dan Saragih, 2018). Proses pengukusan yang diketahui dapat menurunkan indeks glikemik beras karena mengalami pemanasan yang menyebabkan pati mengalami gelatinisasi (Septianingrum et al., 2016).

Muatan glikemik dapat dihitung untuk mengetahui pengaruh konsumsi pangan terhadap peningkatan kadar glukosa darah. Muatan glikemik nasi analog dihasilkan sebesar 28,92 (kategori tinggi). Hasil yang diperoleh ini termasuk ke dalam kategori tinggi karena muatan glikemik yang diperoleh lebih dari 20. Muatan glikemik dikategorikan menjadi 3 diantaranya muatan glikemik rendah $(\leq 10)$, muatan glikemik sedang (11-19) dan muatan glikemik tinggi $(\geq 20)$.

\section{KESIMPULAN}

Sensoris beras analog yang diformulasi dari mocaf, tepung ubi jalar ungu dan tepung jelai secara umum diterima oleh panelis. Aktivitas antioksidan $\left(\mathrm{IC}_{50}\right)$ beras analog berkisar antara 115,33 $\pm 1,1$ sampai dengan 242,8 $\pm 0,31 \mu \mathrm{m} / \mathrm{mL}$. Berdasarakan hasil uji Independent T-test nilai gizi tertinggi (energi, karbohidrat, protein dan lemak)beras analog diperoleh perlakuan mocaf 50, tepung ubi jalar ungu $40 \mathrm{~g}$ dan tepung jelai $10 \mathrm{~g}$, memiliki kadar air 5,71\%; kadar abu 0,73\%; kadar lemak 3,94\%; kadar protein 2,29\%; kadar karbohidrat $87,26 \%$ dan total energi 393,69 kkal. Hasil analisis FTIR diperoleh serapan O-H merupakan pembentuk senyawa fenol sebagai sumber antioksidan pada beras analog. Indeks glikemik beras analog sebesar 33,15 (rendah) dan muatan glikemik sebesar 28,92 (kategori tinggi).

\section{UCAPAN TERIMAKASIH}

Terimakasih pada kementerian pendidikan dan kebudayaan, Dirjen Dikti dalam pendanaan penelitian dengan kotrak Nomor : 048/SP2H/LT/LT/DRPM/2020 tanggal 9 Maret 2020 dan semua yang telah membantu penelitian serta Lab Terpadu UGM atas analisis FTIR.

\section{DAFTAR PUSTAKA}

AOAC. 2005. Official of Analysis of The Association of Analytical Chemistry. Arlington. AOAC Inc.

Aoran Li, Ruoshi Xiao, Sijia He, Xiaoyu An, Yi He, Chengtao Wang, Sheng Yin, Bin Wang, Xuewei Shi, dan Jingren He, 2019. Research Advances of Purple Sweet Potato Anthocyanins: Extraction, Identification, Stability, Bioactivity, Application, and Biotransformation. Molecules. 24(21): 3816. doi: 10.3390/molecules24213816 
Badan Ketahanan Pangan RI, 2020. Petunjuk Diversifikasi Pangan Non Beras 2020. BKP Kementan. Jakarta

Durazzo, A., Kiefer, J., Lucarini, M., Camilli, E., Marconi, S., Gabrielli, P., Aguzzi, A., Gambelli, L., Lisciani, S. dan Marletta, L. 2018a. Qualitative Analysis of Traditional Italian Dishes: FTIR Approach. Sustainability, 10 (4112); 1-13 doi:10.3390/su10114112

Durazzo, A., Kiefer, J., Lucarini, M., Marconi, S. Lisciani, S. Camilli, E., Gambelli, L., Gabrielli, P., Aguzzi, A., Finotti, E., et al. 2018b. An innovative and integrated food research approach: Spectroscopy applications to milk and a case study of a milk-based dish. Braz. J. Anal. Chem, 5, 12-27.

Fitri, R., dan Yekti, W. 2014. Hubungan Konsumsi Karbohidrat, Konsumsi Total Energi, Konsumsi Serat, Beban Glikemik dan Latihan Jasmani dengan Kadar Glukosa Darah Pada Pasien Diabetes Mellitus Tipe 2. Jurnal JNH UNDIP, 2(3):1-27

Ginting, E., J.S. Utomo., R. Yulifiani., dan M. Jusuf. 2011. Potensi ubi jalar ungu sebagai pangan fungsional. Iptek Tanaman Pangan, 6 (1): 116-133.

Handawi, P.S. 2010. Kajian Keterkaitan Produksi, Perdagangan dan Konsumsi Ubi Jalar untuk Meningkatkan 30\% Partisipasi Konsumsi Mendukung Proses Keanekaragaman Pangan dan Gizi. Seminar Nasional. http//www anneahira.com/Artikel Umum/Agribisnis.htm. Kantor Deputi Menegristek. Ubi Jalar/Ketela rambat (Ipomoea batatas $L$ ).

Hardiana, Z., Rudiansyah, Zaharah, T.A., 2012. Aktivitas antioksidan senyawa golongan fenol dari beberapa jenis tumbuhan famili Malvaceae. JKK 1 (1):8-13

Hutami, F. D., dan Harijono. 2014. Pengaruh penggantian larutan dan konsentrasi $\mathrm{NaHCO}_{3}$ terhadap penurunan kadar sianida pada pengolahan tepung ubi kayu. Jurnal Pangan dan Agroindustri. $\quad$ 2(4): 220-230.

Leighton, C.S., Schoenfeldt dan Kruger. 2010. Quantitative descriptive sensory analysis of five different cultivars of sweetpotato to determine sensory and textural profiles. J. Sensory Studies 25: 2-18.

Lucarini, M., Durazzo, A.,Sánchez Del Pulgar, J., Gabrielli, P., dan Lombardi-Boccia, G. 2018. Determination of fatty acid content in meat and meat products: The FTIRATR approach. Food Chem, 267, 223-230.

Marfuatul dan Saragih, B. 2018. Pengaruh Tepung Daun Singkong (Manihot utilissima) terhadap Sensori dan Aktivitas Antioksidan Beras Analog. Jurnal Pertanian Terpadu. 6(2): 96-108. http://ojs.stiperkutim.ac.id/index.php/jpt/article/view/171

Miller, J.B., Foster-Powel, K. dan Colagiuri, S. 1996. The GI Factors; The GI Solution Hodder and Stougton. Hodder Headline. Pty. Limitted. Australia

Noviasari, S., Kusnandar, F., dan Budijanto, S. 2013. Pengembangan Beras Analog dengan Memanfaatkan Jagung Putih. Jurnal Teknologi dan Industri Pangan, 24: 195-201. Doi:10.6066/jtip.2013.24.2.195.

Passos, T.U., Sampaio, H., Arruda, S., Melo, M., Lima,J., dan Rocha, D. 2014. Rice and Bean: Glycemic Index and Glycemic Load of The "Baiao De Dois". Agricultural Science Journal, 5:770-775

Passos, T.U., Sampaio,H..A.C., Sabry M. O. D., Melo, M.L. P., Coelho, M. A. M., dan Lima, J. W. O. 2015. Glycemic Index and Glycemic Load of Tropical Fruits and The Potential Risk For Chronic Diseases. Food Science and Technology, 35(1):66-73

Qi M., Guo Y., Li S., dan He J. 2015. Effect of different Chinese cooking hot processing on anthocyanin content in fresh food and processed purple sweet potato. Food Nutr. China, 21:28-31 
Saragih, B., Marwati., Suprapto, H., Saragih, B., dan Rachmawati, N. 2013. Effect of Various Type of Herbs on Sensory Properties and Blood Glucosa Response Adan Instant Black Rice. International Journal of Science and Engineering, 5(1) : 4248.

Saragih, B. 2013. Analisis Mutu Tepung Bonggol Pisang dari Berbagai Varietas dan Umur Panen $9(1): 22-29$ yang Berbeda. Jurnal TIBBS Teknologi Industri Boga dan Busana,

Saragih, B. 2014. Glikemik Respon Cookies Labu Kuning (Curcuboga Moschata Durrch). Jurnal Boga dan Gizi, 8(1) : 11-15

Saragih, B., 2018. Glycemic Index and Functional Properties of Jelai (Coix lacryma-Jobi L). Proceeding International Conference on Tropical Agrifood, Feed and Fuel (ICTAFF). $\quad$ ttps://www.researchgate.net/publication/329466218

Saragih, B., Rahmadi, A dan Sari D.N. 2019. The effect of steaming duration on nutrition composition, glycemic index and load of analog rice from natural products East Kalimantan. International journal of recent scientific research. 10(02):3107231075, http://dx.doi.org/10.24327/ijrsr.2019.1002.3186

Samad, Y., 2003. Pembuatan Beras Tiruan (Artificial Rice) dengan Bahan Baku Ubi Kayu Dan Sagu, Jurnal Saint dan Teknologi, II; 36-40.

Septianingrum, E., Liyanan dan Kusbiantoro, B. 2016. Rice Glycemic Index: The Factors Affecting and The Impact on Human Health. Jurnal Kesehatan, 1(1) : 1-9.

Shekhar, T. C., dan Anju, G. 2014. Antioxidant Activity by DPPH Radical Scavenging Method of Ageratum conyzoides Linn. Leaves. American Journal of Ethnomedicine, 1(4): 244249

Skoog, D. A., Hollen, F. J. dan Nieman T.A. 1998. Principle of Instrument Analysis,Fourth Edition,Saunders College Publishing,Tokyo.

Subagio, A. 2006. Ubi kayu substitusi berbagai tepung-tepungan. Food Review, 1 (3): 1822.

Subagio, A., Siti, W., Witono, Y., dan Fahmi, F. 2008. Prosedur operasi standart produksi mocal berbasis klaster. Southeast Asia Food \& Agricultural Science \& Teknology (SEAFAST). Institut Pertanian Bogor, Bogor

Sudarmadji, S., B, Haryono., dan Suhardi. 2010. Analisa Bahan Makanan dan Pertanian. Liberty. Yogyakarta.

Sui, X., Bary, S. dan Zhou, W. 2016. Changes in the color, chemical stability and antioxidant capacity of thermally treated anthocyanin aqueous solution over storage. Food Chemistry, 192, 516- 524. doi:10.1016/j.foodchem.2015.07.021

Suwikatmono, Adi., G. Himawan., dan J. Kato. 2013. Modifikasi fisik tepung ubi jalar dan aplikasinya dalam pengembangan produk bihun. Jurnal Penelitian dan Pengembangan Pertanian, 30(5): 120-130.

Steel, R. G. D dan Torrie, J. H. 1995. Prinsip dan Prosedur Statistika (Suatu Pendekatan). Terjemahan. Gramedia Pustaka. Jakarta.

Tajalifar, M. 2018. Coix Seeds: Health and Medicinal Benefits. J Plant Genet Breed, 2(2) 1000108

Talapessy, S., Suryanto, E., dan Yudistira, A. 2013. Uji aktivitas antioksidan dari ampas hasil pengolahan sagu (metroxylon sagu rottb). Jurnal Ilmiah Farmasi, 2(3), 40-44.

Winarno, F.G. 2008. Kimia Pangan dan Gizi. Edisi Terbaru. M-Brio Press. Jakarta.

Zhu, F. 2017. Coix: Chemical composition and health effects. Trends Food Sci Technol, 61: 160-175. 